\title{
Spectrophotometric Determination of Iron(II) and Cobalt(II) by Direct, Derivative, and Simultaneous Methods Using 2-Hydroxy-1-Naphthaldehyde-p-Hydroxybenzoichydrazone
}

\author{
V. S. Anusuya Devi ${ }^{1}$ and V. Krishna Reddy ${ }^{2}$ \\ ${ }^{1}$ Department of Chemistry, S.E.A. College of Engineering and Technology, Bangalore 560049, India \\ ${ }^{2}$ Department of Chemistry, Sri Krishnadevaraya University, Anantapur 515003, India \\ Correspondence should be addressed to V. S. Anusuya Devi, anukmp@gmail.com
}

Received 5 September 2011; Revised 24 October 2011; Accepted 3 November 2011

Academic Editor: Ricardo Vessecchi

Copyright (C) 2012 V.S. A. Devi and V. K. Reddy. This is an open access article distributed under the Creative Commons Attribution License, which permits unrestricted use, distribution, and reproduction in any medium, provided the original work is properly cited.

\begin{abstract}
Optimized and validated spectrophotometric methods have been proposed for the determination of iron and cobalt individually and simultaneously. 2-hydroxy-1-naphthaldehyde-p-hydroxybenzoichydrazone (HNAHBH) reacts with iron(II) and cobalt(II) to form reddish-brown and yellow-coloured [Fe(II)-HNAHBH] and [Co(II)-HNAHBH] complexes, respectively. The maximum absorbance of these complexes was found at $405 \mathrm{~nm}$ and $425 \mathrm{~nm}$, respectively. For [Fe(II)-HNAHBH], Beer's law is obeyed over the concentration range of $0.055-1.373 \mu \mathrm{g} \mathrm{mL}^{-1}$ with a detection limit of $0.095 \mu \mathrm{g} \mathrm{mL}^{-1}$ and molar absorptivity $\varepsilon, 5.6 \times 10^{4} \mathrm{~L} \mathrm{~mol}^{-1}$ $\mathrm{cm}^{-1}$. [Co(II)-HNAHBH] complex obeys Beer's law in $0.118-3.534 \mu \mathrm{g} \mathrm{mL} L^{-1}$ range with a detection limit of $0.04 \mu \mathrm{g} \mathrm{mL} \mathrm{m}^{-1}$ and molar absorptivity, $\varepsilon$ of $2.3 \times 10^{4} \mathrm{~L} \mathrm{~mol}^{-1} \mathrm{~cm}^{-1}$. Highly sensitive and selective first-, second- and third-order derivative methods are described for the determination of iron and cobalt. A simultaneous second-order derivative spectrophotometric method is proposed for the determination of these metals. All the proposed methods are successfully employed in the analysis of various biological, water, and alloy samples for the determination of iron and cobalt content.
\end{abstract}

\section{Introduction}

Iron and cobalt salts are widely used in industrial materials $[1,2]$, paint products [3], fertilizers, feeds, and disinfectants. They are important building components in biological systems [4]. Special cobalt-chromium-molybdenum alloys are used for prosthetic parts such as hip and knee replacements [5]. Iron-cobalt alloys are used for dental prosthetics [6]. There has been growing concern about the role of iron and cobalt in biochemical and environmental systems. Normally small amounts of iron and cobalt are essential for oxygen transport and enzymatic activation, respectively, in all mammals. But excessive intake of iron causes siderosis and damage to organs [7]. A high dosage of cobalt is very toxic to plants and moderately toxic to mammals when injected intravenously. Hence, quantification of various biological samples for iron and cobalt is very important to know their influence on these systems.
A good number of reviews have been made on the use of large number of chromogenic reagents for the spectrophotometric determination of iron and cobalt. Some of the recently proposed spectrophotometric methods for the determination of iron [8-15] and cobalt [16-22] are less sensitive and less selective. We are now proposing simple, sensitive and selective direct and derivative spectrophotometric methods for the determination of iron(II) and cobalt(II) in various complex materials using 2-hydroxy-1-naphthaldehyde-phydroxybenzoichydrazone as chromogenic agent. We are also reporting a highly selective second-order derivative method for the simultaneous determination of iron and cobalt in different samples.

\section{Experimental}

2.1. Preparation of Reagents. $0.01 \mathrm{M}$ iron(II) and cobalt(II) solutions were prepared by dissolving appropriate amounts 


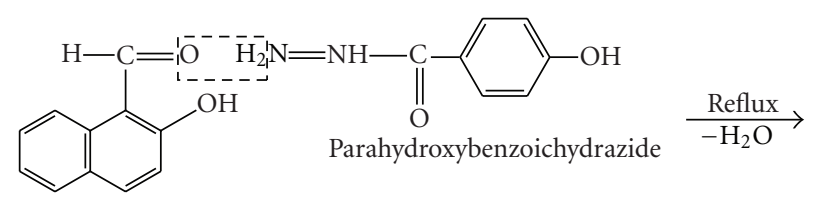

2-hydroxy-1-naphthaldehyde

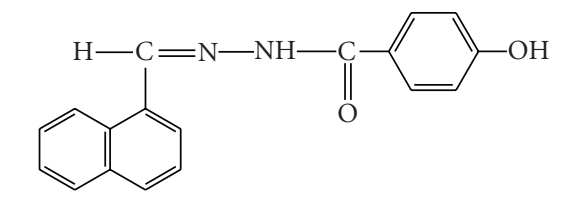

2-hydroxy-1-naphthaldehyde-p-hydroxybenzoichydrazone

Scheme 1

of ferrous ammonium sulphate ( $\mathrm{Sd}$. Fine) in $2 \mathrm{M}$ sulphuric acid and cobaltous nitrate (Qualigens) in $100 \mathrm{~mL}$ distilled water. The stock solutions were diluted appropriately as required. Other metal ion solutions were prepared from their nitrates or chlorides in distilled water. $1 \%$ solution of cetyltrimethylammonium bromide (CTAB), a cationic surfactant in distilled water is used. Buffer solutions of $\mathrm{pH} 1-10$ are prepared using appropriate mixtures of $1 \mathrm{M}$ $\mathrm{HCl}-1 \mathrm{M} \mathrm{CH}_{3} \mathrm{COONa}\left(\mathrm{pH} 1-3.0\right.$ ), $0.2 \mathrm{M} \mathrm{CH}_{3} \mathrm{COOH}, 0.2 \mathrm{M}$ $\mathrm{CH}_{3} \mathrm{COONa}(\mathrm{pH} 3.5-7.0)$, and $1 \mathrm{M} \mathrm{NH}_{4} \mathrm{OH}$ and $1 \mathrm{M} \mathrm{NH}_{4} \mathrm{Cl}$ ( $\mathrm{pH}$ 7.5-10.0). HNAHBH was prepared by mixing equal amounts of 2-hydroxy-1-naphthaldehyde in methanol and p-hydroxybenzoichydrazide in hot aqueous ethanol in equal amounts and refluxing for three hours on water bath. A reddish brown coloured solid was obtained on cooling. The product was filtered and dried. It was recrystallized from aqueous ethanol in the presence of norit. The product showed melting point $272-274^{\circ} \mathrm{C}$.

The structure of the synthesized HNAHBH was determined from infrared and NMR spectral analysis. $1 \times 10^{-2} \mathrm{M}$ solution of the reagent was prepared by dissolving $0.306 \mathrm{~g}$ in $100 \mathrm{~mL}$ of dimethylformamide (DMF). Working solutions were prepared by diluting the stock solution with DMF (see Scheme 1).

\subsection{Preparation of Sample Solutions}

2.2.1. Soil Samples. The soil sample $(5.0 \mathrm{~g})$ was weighed into a $250 \mathrm{~mL}$ Teflon high-pressure microwave acid digestion bomb and $50 \mathrm{~mL}$ aquaregia were added. The bomb was sealed tightly and then positioned in the carousel of a microwave oven. The system was operated at full power for 30 minutes. The digested material was evaporated to incipient dryness. Then, $50 \mathrm{~mL}$ of $5 \%$ hydrochloric acid was added and heated close to boiling to leach the residue. After cooling, the residue was filtered and washed two times with a small volume of $5 \%$ hydrochloric acid. The filtrates were quantitatively collected in a $250 \mathrm{~mL}$ volumetric flask and diluted to the mark with distilled water.

2.2.2. Alloy Steel Sample Solution. A $0.1-0.5 \mathrm{~g}$ of the alloy sample was dissolved in a mixture of $2 \mathrm{~mL} \mathrm{HCl}$ and $10 \mathrm{~mL}$
$\mathrm{HNO}_{3}$. The resulting solution was evaporated to a small volume. To this, $5 \mathrm{~mL}$ of $1: 1 \mathrm{H}_{2} \mathrm{O}$ and $\mathrm{H}_{2} \mathrm{SO}_{4}$ mixture was added and evaporated to dryness. The residue was dissolved in $15 \mathrm{~mL}$ of distilled water and filtered through Whatman filter paper no. 40. The filtrate was collected in a $100 \mathrm{~mL}$ volumetric flask and made upto the mark with distilled water. The solution was further diluted as required.

2.2.3. Food and Biological Samples. A wet ash method was employed in the preparation of the sample solution. $0.5 \mathrm{~g}$ of the sample was dissolved in a $1: 1$ mixture of nitric acid and perchloric acid. The solution was evaporated to dryness, and the residue was ashed at $300^{\circ} \mathrm{C}$. The ash was dissolved in $2 \mathrm{~mL}$ of $1 \mathrm{M}$ sulphuric acid and made up to the volume in a $25 \mathrm{~mL}$ standard flask with distilled water.

2.2.4. Blood and Urine Samples. Blood and urine samples of the normal adult and patient (male) were collected from Government General Hospital, Kurnool, India. $50 \mathrm{~mL}$ of sample was taken into $100 \mathrm{~mL}$ Kjeldal flask. $5 \mathrm{~mL}$ concentrated $\mathrm{HNO}_{3}$ was added and gently heated. When the initial brief reaction was over, the solution was removed and cooled. $1 \mathrm{~mL}$ con. $\mathrm{H}_{2} \mathrm{SO}_{4}$ and $1 \mathrm{~mL}$ of $70 \% \mathrm{HClO}_{4}$ were added. The solution was again heated to dense white fumes, repeating $\mathrm{HNO}_{3}$ addition. The heating was continued for 30 minutes and then cooled. The contents were filtered and neutralized with dil. $\mathrm{NH}_{4} \mathrm{OH}$ in the presence of $1-2 \mathrm{~mL}$ of $0.01 \%$ tartrate solution. The solution was transferred into a $10 \mathrm{~mL}$ volumetric flask and diluted to the volume with distilled water.

2.2.5. Water Samples. Different water samples were collected from different parts of Anantapur district, A. P, India and filtered using Whatman filter paper.

2.2.6. Pharmaceutical Samples. A known quantity of the sample was taken in a beaker and dissolved in minimum volume of alcohol. Then added $3 \mathrm{~mL}$ of $0.01 \mathrm{M}$ nitric acid and evaporated to dryness. The dried mass was again dissolved in alcohol. This was filtered through Whatman filter paper, and the filtrate was diluted to $100 \mathrm{~mL}$ with 
TABLE 1: Tolerance limits of foreign ions, Amount of Fe(II) taken $=0.558 \mu \mathrm{g} \mathrm{mL}-1 \mathrm{pH}=5.0$.

\begin{tabular}{|c|c|c|c|c|c|}
\hline Foreign ion & $\begin{array}{l}\text { Tolerance limit } \\
\left(\mu \mathrm{g} \mathrm{mL}^{-1}\right)\end{array}$ & Foreign ion & $\begin{array}{c}\text { Tolerance limit } \\
\left(\mu \mathrm{g} \mathrm{mL}^{-1}\right)\end{array}$ & Foreign ion & $\begin{array}{l}\text { Tolerance limit } \\
\quad\left(\mu \mathrm{g} \mathrm{mL} L^{-1}\right)\end{array}$ \\
\hline Sulphate & 1440 & $\mathrm{Na}(\mathrm{I})$ & 1565 & $\mathrm{La}(\mathrm{III})$ & 18 \\
\hline Iodide & 1303 & $\operatorname{Mg}(\mathrm{II})$ & 1460 & $\operatorname{Ag}(\mathrm{I})$ & 15 \\
\hline Phosphate & 1424 & $\mathrm{Ca}(\mathrm{II})$ & 1440 & $\mathrm{Hg}(\mathrm{II})$ & 16 \\
\hline Thiosulphate & 1424 & $\mathrm{~K}(\mathrm{I})$ & 1300 & $\mathrm{U}(\mathrm{VI})$ & $6,60^{\mathrm{a}}$ \\
\hline Tartrate & 1414 & $\mathrm{Ba}(\mathrm{II})$ & 1260 & $\mathrm{Mn}(\mathrm{II})$ & $4,55^{\mathrm{a}}$ \\
\hline Thiourea & 1140 & $\operatorname{Pd}(\mathrm{II})$ & 63 & $\operatorname{Th}(\mathrm{IV})$ & $3,50^{\mathrm{a}}$ \\
\hline Bromide & 1138 & $\mathrm{Cd}(\mathrm{II})$ & 45 & $\operatorname{In}(\mathrm{III})$ & $4,60^{\mathrm{a}}$ \\
\hline Nitrate & 930 & $\mathrm{Bi}(\mathrm{III})$ & 42 & $\mathrm{Sn}(\mathrm{II})$ & $<1,50^{\mathrm{a}}$ \\
\hline Carbonate & 900 & $\mathrm{~W}(\mathrm{VI})$ & 37 & $\mathrm{Co}(\mathrm{II})$ & $<1,55^{\mathrm{a}}$ \\
\hline Thiocyanate & 870 & $\mathrm{Hf}(\mathrm{IV})$ & 36 & $\mathrm{Ni}(\mathrm{II})$ & $<1,60^{\mathrm{b}}$ \\
\hline Chloride & 531 & $\mathrm{Ce}(\mathrm{IV})$ & 28 & $\mathrm{Zn}(\mathrm{II})$ & $<1,80^{\mathrm{b}}$ \\
\hline Fluoride & 285 & $\mathrm{Cr}(\mathrm{VI})$ & 27 & $\mathrm{Al}(\mathrm{III})$ & $<1,45^{\mathrm{a}}$ \\
\hline EDTA & 124 & $\mathrm{Mo}(\mathrm{VI})$ & 22 & $\mathrm{Cu}(\mathrm{II})$ & $<1,50^{\mathrm{a}}$ \\
\hline Citrate & 115 & $\mathrm{Zr}(\mathrm{IV})$ & 19 & & \\
\hline Oxalate & 95 & $\mathrm{Sr}(\mathrm{II})$ & 18 & & \\
\hline
\end{tabular}

In the presence of $\mathrm{a}=500 \mu \mathrm{g}$ of tartrate, $\mathrm{b}=400 \mu \mathrm{g}$ of thiocyanate.

TABle 2: Determination of iron in surface soil.

\begin{tabular}{lcc}
\hline Sample & Source of the sample & $\begin{array}{c}\text { Amount of iron } \\
\left(\mathrm{mg} \mathrm{Kg}^{-1}\right) \pm \mathrm{SD}^{*}\end{array}$ \\
\hline S1 & $\begin{array}{c}\text { Groundnut cultivation soil } \\
\text { Akuthotapalli, Anantapur } \\
\text { Cotton cultivation soil, }\end{array}$ & $40.98 \pm 0.45$ \\
S2 & $\begin{array}{c}\text { Singanamala, Anantapur district, } \\
\text { Sweet lemon cultivation soil, } \\
\text { S3 }\end{array}$ & $27.48 \pm 0.36$ \\
Garladinne, Anantapur distrct \\
S4
\end{tabular}

* Average of five determinations.

distilled water. The lower concentrations were prepared by the appropriate dilution of the stock solution.

2.3. Apparatus. A Perkin Elmer (LAMBDA25) spectrophotometer controlled by a computer and equipped with a $1 \mathrm{~cm}$ path length quartz cell was used for UV-Vis spectra acquisition. Spectra were acquired between $350-600 \mathrm{~nm}$ (1 $\mathrm{nm}$ resolution). ELICO model LI-120 pH-meter furnished with a combined glass electrode was used to measure $\mathrm{pH}$ of buffer solutions.

\section{Results and Discussions}

Iron(II) and cobalt(II) react with HNAHBH forming reddish brown and yellow coloured complexes. The colour of the complexes was stable for more than two days.

3.1. Direct Method of Determination of Iron(II). The absorption spectrum of $[\mathrm{Fe}(\mathrm{II})-\mathrm{HNAHBH}]$ shows maximum absorbance at $405 \mathrm{~nm}$. The preliminary investigations indicate that the absorbance of the complex is maximum and stable in $\mathrm{pH}$ range of 4.5-5.5. Hence $\mathrm{pH} 5.0$ was chosen for further studies. A considerable increase in the colour intensity in the presence of $0.1 \%$ CTAB was observed. Studies on reagent (HNAHBH) concentration effect revealed that a maximum of 15 -fold excess reagent is required to get maximum and stable absorbance for the complex. From the absorption spectra of [Fe(II)-HNAHBH] the molar absorptivity, coefficient $\varepsilon$ is calculated as $5.6 \times$ $10^{4} \mathrm{~L} \mathrm{~mol}^{-1} \mathrm{~cm}^{-1}$. Variable amounts of $\mathrm{Fe}(\mathrm{II})$ were treated with suitable amounts of reagent, surfactant, and buffer and the validity of Beer's law was tested by plotting the measured absorbance values of the prepared solutions against concentration of $\mathrm{Fe}(\mathrm{II})$. The calibration curve was linear over the range $0.055-1.373 \mu \mathrm{g} \mathrm{mL}^{-1}$. The composition of the complex [Fe(II) : HNAHBH] was determined as $2: 3$ by Job's continuous variation method and the stability constant of the complex was calculated as $1.8 \times 10^{18}$. Other analytical results are presented in Table 5.

3.1.1. Effect of Diverse Ions in the Determination of Iron by Direct Method. Numerous cations and anions were added individually to the experimental solution containing $0.558 \mu \mathrm{g} \mathrm{mL}^{-1}$ of iron and the influence was examined (Table 1). All the anions and many cations were tolerable in more than 100 fold excess. The tolerance limits of some ions were in the range of 5-50 folds. Some of the metal ions, which strongly interfered, could be masked using appropriate masking agents.

3.1.2. Determination of Iron in Surface Soil and Alloy Steels by Direct Spectrophotometric Method. The applicability of the developed direct method was evaluated by applying the 
TABLE 3: Determination of iron in alloy steels.

\begin{tabular}{lcc}
\hline Alloy steel composition (\%) & $\begin{array}{c}\text { Amount of iron (\%) } \\
\text { Present }\end{array}$ & $\begin{array}{c}\text { Relative } \\
\text { error }(\%)\end{array}$ \\
\hline High tensile steel & Certified value S $^{*}$ & \\
BY0110-1 & & $4.06 \pm 0.021$ \\
$(42.98 \mathrm{Zn}, 19.89 \mathrm{Si}, 0.351 \mathrm{~Pb}, 0.06 \mathrm{Sn}, 0.04 \mathrm{Cd}, 0.024 \mathrm{As}, 0.14 \mathrm{Cu}$, and & 4.13 & 0.17 \\
$4.13 \mathrm{Fe})$ & & $4.18 \pm 0.022$ \\
YSBC19716 & 34.26 & $9.46 \pm 0.039$ \\
(34.26 Zn, $0.38 \mathrm{Si}, 1.2 \mathrm{Cd}, 48.57 \mathrm{Sb}, 0.95 \mathrm{~S}$, and $0.32 \mathrm{~F})$ & 9.53 & 0.01 \\
GSBD33001-94 & & 0.08 \\
\hline (9.29 Al, $1.04 \mathrm{Ca}, 9.53 \mathrm{Fe})$ & &
\end{tabular}

${ }^{*}$ Average of five determinations.

TABLE 4: Tolerance limits of some cations in derivative methods.

\begin{tabular}{lcccc}
\hline Foreign ion & \multicolumn{4}{c}{ Tolerance limit (in folds) } \\
& $\begin{array}{c}\text { Direct } \\
\text { method }\end{array}$ & $\begin{array}{c}\text { First } \\
\text { derivative }\end{array}$ & $\begin{array}{c}\text { Second } \\
\text { derivative }\end{array}$ & $\begin{array}{c}\text { Third } \\
\text { derivative }\end{array}$ \\
\hline $\mathrm{Ag}(\mathrm{I})$ & 14 & 18 & 35 & 22 \\
$\mathrm{Hg}(\mathrm{II})$ & 11 & 20 & 40 & 30 \\
$\mathrm{U}(\mathrm{VI})$ & 11 & 12 & 25 & 18 \\
$\mathrm{Mn}(\mathrm{II})$ & 7 & 20 & 16 & 20 \\
$\mathrm{Th}(\mathrm{IV})$ & 5 & 10 & 16 & 20 \\
$\mathrm{In}(\mathrm{III})$ & 7 & 28 & 48 & 34 \\
$\mathrm{Au}(\mathrm{III})$ & 4 & 35 & 55 & 28 \\
$\mathrm{Sn}(\mathrm{II})$ & $<1$ & 8 & 15 & 22 \\
$\mathrm{Co}(\mathrm{II})$ & $<1$ & interfere & 7 & 15 \\
$\mathrm{Ni}(\mathrm{II})$ & $<1$ & interfere & 5 & 10 \\
$\mathrm{Cu}(\mathrm{II})$ & $<1$ & 5 & 12 & 10 \\
\hline
\end{tabular}

method for the analysis of some surface soil and alloy steel samples for their iron content. Different aliquots of sample solutions containing suitable amounts of iron were treated with known and required volume of $\mathrm{HNAHBH}$ at $\mathrm{pH} 5.0$ and $0.1 \%$ CTAB and diluted to $10 \mathrm{~mL}$ with distilled water. The absorbance of the resultant solutions was measured at $405 \mathrm{~nm}$, and the amount of iron present was computed from the predetermined calibration plot. The results were compared with the certified values and presented in Tables 2 and 3.

3.2. Determination of Iron(II) by Derivative Method. Different amounts of $\mathrm{Fe}(\mathrm{II})\left(0.027-1.375 \mu \mathrm{g} \mathrm{mL}^{-1}\right)$ were treated with suitable amounts of HNAHBH in buffer solutions of pH 5.0 along with $0.1 \%$ CTAB and made upto $10 \mathrm{~mL}$ with distilled water. $1 \mathrm{st}, 2 \mathrm{nd}$, and $3 \mathrm{rd}$ order derivative spectra were recorded in the wavelength region $350-600 \mathrm{~nm}$. The first-order derivative spectra showed maximum derivative amplitude at $427 \mathrm{~nm}$ (Figure 1). The second-order derivative spectra gave one large trough at $421 \mathrm{~nm}$ and a large crust at $435 \mathrm{~nm}$ with zero cross at $428 \mathrm{~nm}$ (Figure 2). A large crust at $415 \mathrm{~nm}$ and a large trough at $426 \mathrm{~nm}$ with zero cross at $421 \mathrm{~nm}$ were observed for the third-derivative spectra
(Figure 3). Hence $\mathrm{Fe}(\mathrm{II})$ was determined by measuring the derivative amplitudes at $427 \mathrm{~nm}$ for 1st order, at $421 \mathrm{~nm}$ and $435 \mathrm{~nm}$ for 2nd order, and at $415 \mathrm{~nm}$ and $426 \mathrm{~nm}$ for $3 \mathrm{rd}$ order spectra.

3.2.1. Determination of Iron(II). The derivative amplitudes measured at the analytical wavelengths as mentioned above for different derivative spectra were plotted against the amount of $\mathrm{Fe}(\mathrm{II})$. The calibration plots are linear in the range $0.027-1.375 \mu \mathrm{g} \mathrm{mL}^{-1}$. All the derivative methods are found to be more sensitive with a wider Beer's law range than the zero order method (Table 5)

3.2.2. Effect of Foreign Ions in Derivative Method of Determination of Iron. The influence of some of the cations, which showed serious interference in zero order method, on the derivative amplitudes was studied by the reported methods and the results obtained are shown in Table 4 . It can be observed from the table that large number of ions showed significantly high-tolerance limits in some of the derivative methods.

3.2.3. Determination of Iron in Food and Biological Samples by First Order Derivative Method. Known aliquots of the prepared food and biological sample solutions were treated with suitable volumes of $\mathrm{HNAHBH}$, buffer solution, and CTAB surfactant and diluted to the volume in $10 \mathrm{~mL}$ volumetric flasks. The first-order derivative spectra were recorded, and the derivative amplitudes were measured at analytical wave lengths. The amounts of Fe(II) in the samples were computed from predetermined calibration plots and presented in Table 6. The food and biological samples were further analyzed by Atomic Absorbance Spectrophotometric method, and the results obtained were compared with those of the present method.

3.3. Direct Method of Determination of Cobalt(II). [Co(II)$\mathrm{HNAHBH}$ ] complex shows maximum absorbance at $425 \mathrm{~nm}$. Maximum and stable absorbance of the complex is achieved in the $\mathrm{pH}$ range of 5.0-7.0. Hence $\mathrm{pH} 6.0$ was chosen for further studies. A marginal increase in the absorbance was observed in presence of $0.15 \%$ of 
TABLE 5: Analytical characteristics of [Fe(II)-HNAHBH].

\begin{tabular}{|c|c|c|c|c|c|c|}
\hline \multirow{2}{*}{ Parameter } & \multirow{2}{*}{$\begin{array}{l}\text { Direct method } \\
405 \mathrm{~nm}\end{array}$} & \multirow{2}{*}{$\begin{array}{l}\text { First derivative } \\
\quad 427 \mathrm{~nm}\end{array}$} & \multicolumn{2}{|c|}{ Second derivative } & \multicolumn{2}{|c|}{ Third derivative } \\
\hline & & & $421 \mathrm{~nm}$ & $435 \mathrm{~nm}$ & $415 \mathrm{~nm}$ & $426 \mathrm{~nm}$ \\
\hline $\begin{array}{l}\text { Beer's law range } \\
\left(\mu \mathrm{gL}^{-1}\right)\end{array}$ & $0.055-1.373$ & $0.027-1.376$ & $0.027-1.376$ & $0.027-1.376$ & $0.027-1.376$ & $0.027-1.376$ \\
\hline $\begin{array}{l}\text { Molar absorptivity, } \\
\left(\mathrm{L} \mathrm{mol}^{-1} \mathrm{~cm}^{-1}\right)\end{array}$ & $5.6 \times 10^{4}$ & & & - & - & - \\
\hline $\begin{array}{l}\text { Sandell's sensitivity, } \\
\left(\mu \mathrm{g} \mathrm{cm}^{-2}\right)\end{array}$ & 0.0012 & & & - & - & - \\
\hline Angular coefficient (m) & 0.974 & 0.072 & 0.006 & 0.093 & 0.002 & 0.085 \\
\hline Y-intercept (b) & 0.0047 & -0.0045 & $-0.1 \times 10^{-3}$ & $-0.1 \times 10^{-3}$ & $0.2 \times 10^{-4}$ & $0.9 \times 10^{-3}$ \\
\hline Correlation coefficient & 0.9997 & 0.9999 & 0.9999 & 0.9999 & 0.9999 & 0.9999 \\
\hline RSD (\%) & 2.19 & 0.85 & 0.76 & 0.89 & 1.31 & 1 \\
\hline $\begin{array}{l}\text { Detection limit } \\
\left(\mu \mathrm{g} \mathrm{mL} L^{-1}\right)\end{array}$ & 0.065 & 0.1 & 0.022 & 0.0268 & 0.036 & 0.304 \\
\hline $\begin{array}{l}\text { Determination limit, } \\
\left(\mu \mathrm{g} \mathrm{mL}^{-1}\right)\end{array}$ & 0.197 & 0.3 & 0.068 & 0.8 & 0.11 & 0.914 \\
\hline Composition $(\mathrm{M}: \mathrm{L})$ & $2: 3$ & - & - & & - & \\
\hline Stability constant & $1.8 \times 10^{18}$ & - & - & & - & \\
\hline
\end{tabular}

TABLE 6: Determination of iron in food and biological samples.

\begin{tabular}{|c|c|c|c|c|c|c|}
\hline \multirow{3}{*}{ Samples } & \multicolumn{6}{|c|}{ Amount of iron $\left(\mu \mathrm{g} \mathrm{mL}^{-1}\right) \pm \mathrm{SD}(n=4)$} \\
\hline & \multicolumn{2}{|c|}{ Found } & \multicolumn{4}{|c|}{ Recovered } \\
\hline & present & AAS & Added & present & AAS & recovery \\
\hline Wheat & $6.68 \pm 0.18$ & $6.40 \pm 0.09$ & 5 & $11.40 \pm 1.15$ & $11.28 \pm 0.10$ & 97.6 \\
\hline Rice & $14.10 \pm 40.25$ & $16.46 \pm 0.18$ & 5 & $19.7 \pm 40.27$ & $21.04 \pm 0.48$ & 102 \\
\hline Tomato & $11.96 \pm 1.20$ & $12.68 \pm 0.14$ & 5 & $17.68 \pm 0.25$ & $17.44 \pm 0.95$ & 104 \\
\hline Orange & $18.12 \pm 0.73$ & $16.94 \pm 0.66$ & 5 & $22.20 \pm 0.75$ & $22.26 \pm 0.68$ & 96 \\
\hline Banana & $10.12 \pm 1.46$ & $11.4 \pm 0.12$ & 5 & $14.86 \pm 1.45$ & $15.86 \pm 1.46$ & 98.3 \\
\hline Prostate gland & $3.26 \pm 0.28$ & $2.98 \pm 0.08$ & 6.5 & $10.04 \pm 1.68$ & $9.54 \pm 0.94$ & 103 \\
\hline Benign (enlarged prostate gland & $12.38 \pm 3.18$ & $13.15 \pm 1.18$ & 6.5 & $17.96 \pm 1.56$ & $20.18 \pm 1.66$ & 95.12 \\
\hline
\end{tabular}

TABLE 7: Tolerance limits of foreign ions, amount of $\mathrm{Co}(\mathrm{II})$ taken $=1.767 \mu \mathrm{g} \mathrm{mL}^{-1}, \mathrm{pH}=6.0$.

\begin{tabular}{|c|c|c|c|c|c|}
\hline Foreign ion & Tolerance limit $\left(\mu \mathrm{g} \mathrm{mL}^{-1}\right)$ & Foreign ion & Tole limit $\left(\mu \mathrm{g} \mathrm{mL} L^{-1}\right)$ & Foreign ion & Toler limit $\left(\mu \mathrm{g} \mathrm{mL}^{-1}\right)$ \\
\hline Tartrate & 1707 & $\mathrm{Na}(\mathrm{I})$ & 1666 & $\mathrm{Au}(\mathrm{III})$ & 20 \\
\hline Phosphate & 1425 & $\operatorname{Mg}(\mathrm{II})$ & 1530 & $\mathrm{Sr}(\mathrm{II})$ & 18 \\
\hline Sulphate & 1440 & $\mathrm{Ca}(\mathrm{II})$ & 1426 & $\mathrm{Mo}(\mathrm{VI})$ & 15 \\
\hline Oxalate & 1320 & $\mathrm{~K}(\mathrm{I})$ & 1200 & $\mathrm{Tl}(\mathrm{IV})$ & 13 \\
\hline Bromide & 1198 & $\mathrm{Ba}(\mathrm{II})$ & 1162 & $\mathrm{Pd}(\mathrm{II})$ & $11,100^{c}$ \\
\hline Thiourea & 1140 & $\mathrm{Hf}(\mathrm{IV})$ & 72 & $\operatorname{Th}(\mathrm{IV})$ & $6,60^{\mathrm{a}}$ \\
\hline Thiosulphate & 1120 & $\mathrm{Se}(\mathrm{IV})$ & 64 & $\mathrm{U}(\mathrm{VI})$ & $5,60^{\mathrm{a}}$ \\
\hline Nitrate & 930 & $\mathrm{Cd}(\mathrm{II})$ & 56 & $\mathrm{Mn}(\mathrm{II})$ & $5,50^{\mathrm{a}}$ \\
\hline Chloride & 525 & $\mathrm{~W}(\mathrm{VI})$ & 55 & $\mathrm{Cu}(\mathrm{II})$ & $2,50^{\mathrm{a}}$ \\
\hline Carbonate & 300 & $\mathrm{Zr}(\mathrm{IV})$ & 46 & $\mathrm{Ni}(\mathrm{II})$ & $<1,80^{\mathrm{b}}$ \\
\hline Fluoride & 285 & $\mathrm{~Pb}(\mathrm{II})$ & 42 & $\mathrm{Zn}(\mathrm{II})$ & $<1$ \\
\hline EDTA & 144 & $\mathrm{Hg}(\mathrm{II})$ & 40 & $\operatorname{Sn}(\mathrm{II})$ & $<1$ \\
\hline \multirow[t]{3}{*}{ Citrate } & 115 & $\mathrm{Cr}(\mathrm{VI})$ & 26 & $\operatorname{In}(\mathrm{III})$ & $<1,60^{\mathrm{a}}$ \\
\hline & & $\mathrm{Bi}(\mathrm{III})$ & 21 & $\mathrm{Ga}(\mathrm{III})$ & $<1,50^{\mathrm{a}}$ \\
\hline & & $\mathrm{Ru}(\mathrm{III})$ & 21 & $\mathrm{~V}(\mathrm{~V})$ & $<1,50^{\mathrm{b}}$ \\
\hline
\end{tabular}

In the presence of $a=700 \mu \mathrm{g}$ of tartrate, $b=400 \mu \mathrm{g}$ of oxalate and $c=500 \mu \mathrm{g}$ of thiourea. 
TABLE 8: Determination of cobalt in surface soil samples.

\begin{tabular}{|c|c|c|c|}
\hline & \multirow[t]{2}{*}{ Sample and source } & \multicolumn{2}{|c|}{ Cobalt $\left(\mu \mathrm{g} \mathrm{mL}^{-1}\right)$} \\
\hline & & $\begin{array}{l}\text { Present } \\
\text { method* }^{*}\end{array}$ & $\begin{array}{c}\text { Reference method } \\
{[23]}\end{array}$ \\
\hline S1 & $\begin{array}{l}\text { Agricultural land } \\
\text { (red soil Anantapur.) }\end{array}$ & $16.48 \pm 0.030$ & $17.20 \pm 0.024$ \\
\hline S2 & $\begin{array}{l}\text { Agricultural land } \\
\text { (black soil, Tadipatri.) }\end{array}$ & $24.15 \pm 0.026$ & $23.68 \pm 0.022$ \\
\hline S3 & $\begin{array}{l}\text { Riverbed soil } \\
\text { (Tungabhadra river, } \\
\text { Kurnool) }\end{array}$ & $14.68 \pm 0.034$ & $15.26 \pm 0.018$ \\
\hline S4 & $\begin{array}{l}\text { Industrial soil } \\
\text { (electroplating } \\
\text { industry, Anantapur) }\end{array}$ & $118.40 \pm 0.042$ & $122.12 \pm 0.029$ \\
\hline
\end{tabular}

TABLE 9: Analysis of blood and urine samples for cobalt content.

\begin{tabular}{|c|c|c|c|}
\hline \multirow{2}{*}{ Sample source } & \multirow{2}{*}{ Sample } & \multicolumn{2}{|c|}{ Cobalt $\left(\mu \mathrm{g} \mathrm{mL}^{-1}\right)$} \\
\hline & & $\begin{array}{c}\text { Present } \\
\text { method } \pm \mathrm{SD} \\
(n=5)\end{array}$ & $\begin{array}{c}\text { AAS method } \pm \mathrm{SD} \\
(n=5)\end{array}$ \\
\hline \multirow{2}{*}{$\begin{array}{l}\text { Normal adult } \\
\text { (male) }\end{array}$} & Blood & $2.44 \pm 0.020$ & $2.48 \pm 0.014$ \\
\hline & Urine & $0.38 \pm 0.010$ & $0.35 \pm 0.022$ \\
\hline \multirow{2}{*}{$\begin{array}{l}\text { Anemia patient } \\
\text { (female) }\end{array}$} & Blood & $0.86 \pm 0.020$ & $0.92 \pm 0.020$ \\
\hline & Urine & $0.24 \pm 0.030$ & $0.23 \pm 0.014$ \\
\hline \multirow{2}{*}{ Paralysis patient } & Blood & $8.46 \pm 0.030$ & $8.65 \pm 0.032$ \\
\hline & Urine & $2.65 \pm 0.020$ & $2.43 \pm 0.025$ \\
\hline \multirow{2}{*}{ Pulmonary patient } & Blood & $4.32 \pm 0.015$ & $4.26 \pm 0.010$ \\
\hline & Urine & $1.96 \pm 0.022$ & $2.04 \pm 0.018$ \\
\hline
\end{tabular}

TABLE 10: Tolerance limit of foreign ions $\left(\mu \mathrm{g} \mathrm{mL}{ }^{-1}\right)$.

\begin{tabular}{lccc}
\hline Diverse ion & Zero order & Second derivative & Third derivative \\
\hline Th(IV) & 6 & 55 & 35 \\
U(VI) & 5 & 40 & 45 \\
$\mathrm{Mn}(\mathrm{II})$ & 5 & 60 & 20 \\
$\mathrm{Cu}(\mathrm{II})$ & 2 & 80 & 45 \\
$\mathrm{Ni}(\mathrm{II})$ & $<1$ & 30 & 50 \\
$\mathrm{Zn}(\mathrm{II})$ & $<1$ & 45 & 20 \\
$\mathrm{Sn}(\mathrm{II})$ & $<1$ & 25 & 18 \\
$\mathrm{In}(\mathrm{III})$ & $<1$ & 15 & 28 \\
$\mathrm{Ga}(\mathrm{III})$ & $<1$ & 20 & 35 \\
$\mathrm{~V}(\mathrm{~V})$ & $<1$ & 15 & 20 \\
\hline
\end{tabular}

CTAB. 10-folds excess of HNAHBH is sufficient to get maximum absorbance. Molar absorptivity of the complex was calculated as $2.3 \times 10^{4} \mathrm{~L} \mathrm{~mol}^{-1} \mathrm{~cm}^{-1}$. Beer's law is tested taking the different amounts of $\mathrm{Co}$ (II) in presence of suitable buffer, surfactant, and $\mathrm{HNAHBH}$, linearity of the calibration curve is found between $0.118-3.534 \mu \mathrm{g} \mathrm{mL}^{-1}$ with a detection limit of $0.04 \mu \mathrm{g} \mathrm{mL}^{-1}$ and determination limit $0.124 \mu \mathrm{g} \mathrm{mL}^{-1}$ (Table 11 ), which shows the sensitivity of the present method. The stoichiometry of the complex

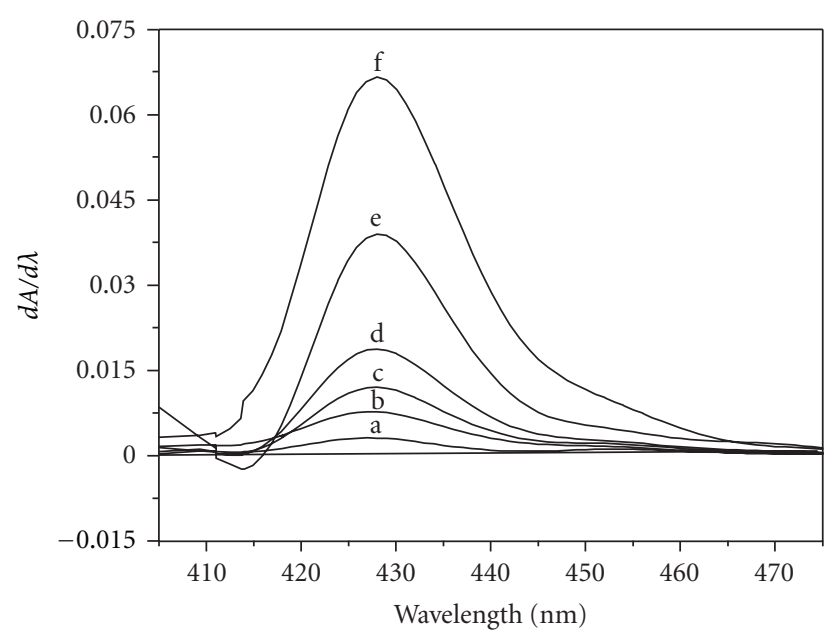

Figure 1: First-order derivative spectra of [Fe(II)-HNAHBH]. Amount of $\mathrm{Fe}(\mathrm{II}) \mu \mathrm{g} \mathrm{mL}^{-1}: \mathrm{a}=0.027 ; \mathrm{b}=0.055 ; \mathrm{c}=0.11 ; \mathrm{d}=$ $0.22 ; \mathrm{e}=0.33 ; \mathrm{f}=0.88$.

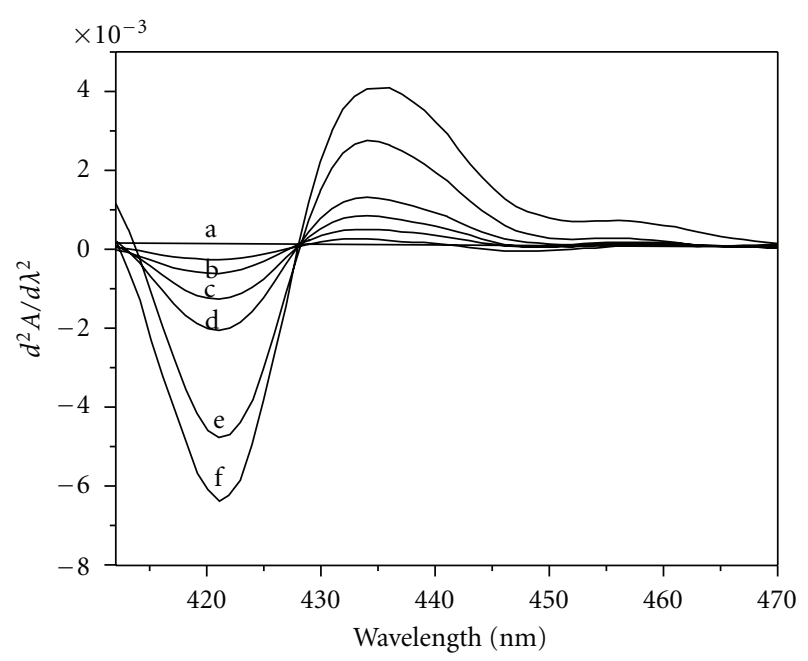

FIgure 2: Second-order derivative spectra of [Fe(II)-HNAHBH]. Amount of $\mathrm{Fe}(\mathrm{II}) \mu \mathrm{g} \mathrm{mL}^{-1}: \mathrm{a}=0.027 ; \mathrm{b}=0.055 ; \mathrm{c}=0.11 ; \mathrm{d}=$ $0.22 ; \mathrm{e}=0.33 ; \mathrm{f}=0.88$.

was found to be 2:3 (Metal:Ligand) by Job's method. The stability constant is calculated as $7.7 \times 10^{19}$.

3.3.1. Effect of Foreign Ions in the Determination of Cobalt by Direct Method. The effect of various anions and cations normally associated with $\mathrm{Co}$ (II) on the absorbance of the experimental solution was studied. The tolerance limits of the tested foreign ions, which bring about a change in the absorbance by $\pm 2 \%$ were calculated and presented in Table 7 .

Among anions, except EDTA and citrate, all other tested ions were tolerable in more than 200-fold excess. EDTA and citrate were tolerable in 144- and 150-fold excess, respectively. Of the tested cations, some of them did not interfere even when present in more than 500 fold excess, many cations were tolerable between $10-80$-folds. Cations which interfere seriously are masked with suitable anions. 
TABLE 11: Analytical characteristics of [Co(II)-HNAHBH].

\begin{tabular}{|c|c|c|c|c|c|}
\hline \multirow{2}{*}{ Parameter } & \multirow{2}{*}{$\begin{array}{l}\text { Direct method } \\
425 \mathrm{~nm}\end{array}$} & \multicolumn{2}{|c|}{ Second derivative } & \multicolumn{2}{|c|}{ Third derivative } \\
\hline & & $431 \mathrm{~nm}$ & $443 \mathrm{~nm}$ & $437 \mathrm{~nm}$ & $449 \mathrm{~nm}$ \\
\hline Beer's law range $\left(\mu \mathrm{g} \mathrm{mL}^{-1}\right)$ & $0.118-3.534$ & $0.059-4.712$ & $0.059-4.712$ & $0.059-1.380$ & $0.056-1.380$ \\
\hline Molar absorptivity, $\left(\mathrm{L} \mathrm{mol}^{-1} \mathrm{~cm}^{-1}\right)$ & $2.3 \times 10^{4}$ & - & - & - & - \\
\hline Sandell's sensitivity, $\mu \mathrm{g} \mathrm{cm}^{-2}$ & 0.003 & - & - & - & - \\
\hline Angular coefficient $(\mathrm{m})$ & 0.375 & 0.0003 & 0.093 & 0.0002 & 0.009 \\
\hline Y-intercept (b) & 0.0197 & $3.2 \times 10^{-5}$ & $-0.9 \times 10^{-4}$ & $-0.2 \times 10^{-4}$ & $-0.9 \times 10^{-4}$ \\
\hline Correlation coefficient & 0.9999 & 0.999 & 0.9999 & 0.9999 & 0.9999 \\
\hline RSD (\%) & 1.37 & 1.84 & 4.3 & 1.15 & 7.6 \\
\hline Detection limit $\left(\mu \mathrm{g} \mathrm{mL}^{-1}\right)$ & 0.04 & 0.06 & 0.13 & 0.04 & 0.21 \\
\hline Determination limit, $\left(\mu \mathrm{g} \mathrm{mL}^{-1}\right)$ & 0.124 & 0.18 & 0.39 & 0.114 & 0.65 \\
\hline Composition (M:L) & $2: 3$ & - & - & & - \\
\hline Stability constant & $7.7 \times 10^{19}$ & - & - & & - \\
\hline
\end{tabular}

TABle 12: Determination of cobalt in environmental water samples.

\begin{tabular}{lcccc}
\hline Sample & \multicolumn{4}{c}{ cobalt $\left(\mu \mathrm{gL}^{-1}\right)$} \\
& Added & Found & $\begin{array}{c}\text { Recovery } \\
(\%)\end{array}$ & $\begin{array}{c}\text { RSD } \\
(\%)\end{array}$ \\
\hline \multirow{3}{*}{$\begin{array}{l}\text { Tap water (municipality water } \\
\text { supply, Anantapur) }\end{array}$} & 0.0 & 0.32 & - & 2.5 \\
& 3.0 & 1.80 & 98.90 & 1.8 \\
& 4.5 & 4.83 & 100.20 & 2.2 \\
\hline \multirow{3}{*}{ River water (Penna, } & 0.0 & 1.52 & - & 3.0 \\
Tadipatri.) & 1.5 & 3.00 & 99.34 & 1.6 \\
& 3.0 & 4.55 & 100.66 & 2.8 \\
& 4.5 & 5.95 & 98.84 & 4.0 \\
\hline \multirow{2}{*}{$\begin{array}{l}\text { Drain water (vanaspati } \\
\text { industry, Tadipatri. }\end{array}$} & 0.0 & 3.60 & - & 1.7 \\
& 1.5 & 5.31 & 104.12 & 3.2 \\
& 3.0 & 6.48 & 98.18 & 2.5 \\
& 4.5 & 8.07 & 99.63 & 3.6 \\
\hline
\end{tabular}

TABLE 13: Determination of cobalt in pharmaceutical tablets.

\begin{tabular}{lccc}
\hline Sample $(\mathrm{mg} /$ tablet $)$ & \multicolumn{2}{c}{ Amount of cobalt $\left(\mu \mathrm{g} \mathrm{mL}^{-1}\right)$} \\
\hline & Reported & Found* & $\begin{array}{r}\text { Relative } \\
\text { error }(\%)\end{array}$ \\
\hline $\begin{array}{l}\text { Neurobion forte } \\
\text { (cyanocobalamine- }\end{array}$ & 7.45 & 7.4 & -0.67 \\
$\begin{array}{l}15 \mathrm{mg}) \\
\begin{array}{l}\text { Basiton forte } \\
\text { (cyanocobalamine- }\end{array}\end{array}$ & 7.42 & 7.24 & -2.42 \\
$15 \mathrm{mg})$ & & \\
${ }^{*}$ Average of four determinations.
\end{tabular}

3.3.2. Determination of Cobalt in Surface Soil, Blood and Urine Samples by Direct Method. Suitable aliquots of the soil, blood, and urine sample solutions were taken and analyzed for cobalt content by the proposed method, and the results are presented in Tables 8 and 9. The soil solutions were further analyzed by a reference method [23], and biological

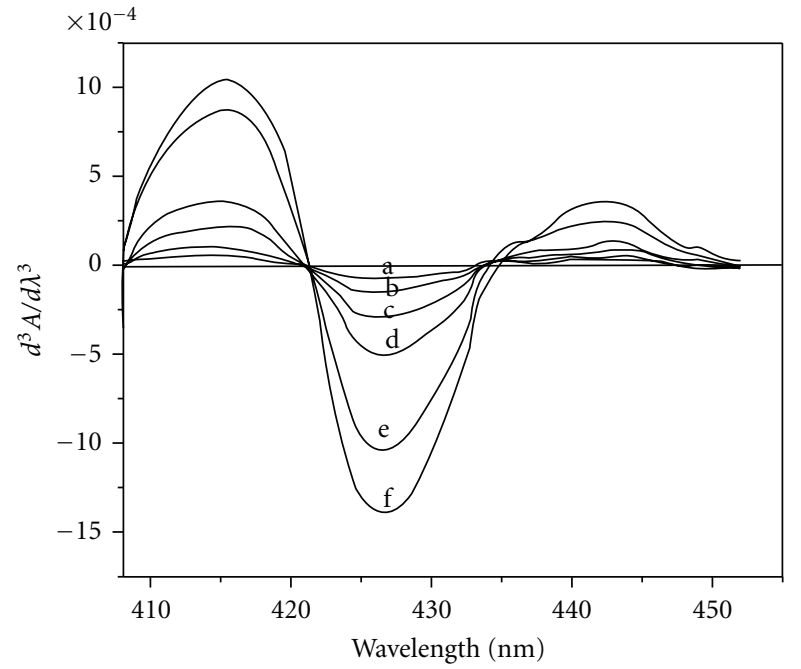

Figure 3: Third-order derivative spectra of [Fe(II)-HNAHBH]. Amount of Fe(II) $\mu$ g mL-1: $\mathrm{a}=0.027 ; \mathrm{b}=0.055 ; \mathrm{c}=0.11 ; \mathrm{d}=$ $0.22 ; \mathrm{e}=0.33 ; \mathrm{f}=0.88$.

samples were analyzed by flame atomic absorption spectrophotometer, and the results obtained were compared with those of present method, which indicate the acceptability of the present method.

3.4. Determination of Cobalt by Derivative Method. Variable amounts $\left(0.059-4.712 \mu \mathrm{g} \mathrm{mL}{ }^{-1}\right)$ of $\mathrm{Co}$ (II), taken in different $10 \mathrm{~mL}$ volumetric flasks, were treated with optimal amounts of reagent $\mathrm{HNAHBH}$ at $\mathrm{pH} 6.0$ in presence of $0.15 \%$ $\mathrm{CTAB}$, and the derivative spectra were recorded in the wavelength region 350-600 nm against reagent blank. The second-derivative curves (Figure 4 ) gave a trough at $431 \mathrm{~nm}$ and a crust at $443 \mathrm{~nm}$ with a zero cross at $437 \mathrm{~nm}$. In the third-derivative spectra (Figure 5), maximum amplitude was observed at $424 \mathrm{~nm}, 437 \mathrm{~nm}, 449 \mathrm{~nm}$, and at $462 \mathrm{~nm}$ with zero crossings at $431 \mathrm{~nm}, 443 \mathrm{~nm}$, and $456 \mathrm{~nm}$. 
TABLE 14: Linear regression analysis of the determination of $\mathrm{Fe}(\mathrm{II})$ and $\mathrm{Co}(\mathrm{II})$ in mixture by second derivative spectrophotometry.

\begin{tabular}{|c|c|c|c|c|c|c|}
\hline \multirow[t]{2}{*}{ Metal ion determined } & \multirow{2}{*}{ Wave length $(\mathrm{nm})$} & \multicolumn{2}{|c|}{ Other metal present $\left(\mu \mathrm{g} \mathrm{mL}^{-1}\right)$} & \multirow{2}{*}{ Slope } & \multirow{2}{*}{ Intercept } & \multirow{2}{*}{ Correlation coefficient } \\
\hline & & $\mathrm{Fe}(\mathrm{II})$ & $\mathrm{Co}(\mathrm{II})$ & & & \\
\hline \multirow[t]{2}{*}{$\mathrm{Fe}(\mathrm{II})$} & 436 & & & $3.9 \times 10^{-3}$ & $2.4 \times 10^{-4}$ & 0.9994 \\
\hline & & & 0.589 & $3.2 \times 10^{-3}$ & $1.9 \times 10^{-4}$ & 0.9995 \\
\hline \multirow[t]{2}{*}{$\mathrm{Co}(\mathrm{II})$} & 426 & & & $1.4 \times 10^{-4}$ & $2.3 \times 10^{-6}$ & 0.9999 \\
\hline & & 0.33 & & $1.4 \times 10^{-4}$ & $2.0 \times 10^{-6}$ & 0.9998 \\
\hline
\end{tabular}

TABLE 15: Simultaneous second-order derivative spectrophotometric determination of Fe(II) and Co(II).

\begin{tabular}{|c|c|c|c|c|c|}
\hline \multicolumn{2}{|c|}{ Amount taken $\left(\mu \mathrm{g} \mathrm{mL}^{-1}\right)$} & \multicolumn{2}{|c|}{ Amount found ${ }^{*}\left(\mu \mathrm{g} \mathrm{mL}^{-1}\right)$} & \multicolumn{2}{|c|}{ Relative error $(\%)$} \\
\hline $\mathrm{Fe}(\mathrm{II})$ & $\mathrm{Co}(\mathrm{II})$ & $\mathrm{Fe}(\mathrm{II})$ & $\mathrm{Co}(\mathrm{II})$ & $\mathrm{Fe}(\mathrm{II})$ & $\mathrm{Co}(\mathrm{II})$ \\
\hline 0.06 & 0.59 & $0.053(96.3)$ & $0.572(98.8)$ & -3.6 & -2.8 \\
\hline 0.12 & 0.59 & $0.120(103.4)$ & $0.592(100.5)$ & 3.44 & 0.5 \\
\hline 0.23 & 0.59 & $0.230(99.1)$ & $0.586(99.4)$ & -0.86 & -0.5 \\
\hline 0.33 & 0.59 & $0.334(101.2)$ & $0.572(98.8)$ & 1.21 & -2.8 \\
\hline 0.44 & 0.59 & $0.441(100.2)$ & $0.590(100.1)$ & 0.22 & 0.2 \\
\hline 0.55 & 0.59 & $0.542(98.5)$ & $0.586(99.3)$ & -1.45 & -0.5 \\
\hline 0.33 & 0.59 & $0.328(99.3)$ & $1.120(94.9)$ & -0.60 & -0.7 \\
\hline 0.33 & 1.18 & $0.326(89.6)$ & $2.280(96.6)$ & -1.21 & -5.0 \\
\hline 0.33 & 2.36 & $0.324(98.1)$ & $3.600(101.7)$ & -1.81 & -3.3 \\
\hline 0.33 & 3.54 & $0.336(101.8)$ & $4.670(98.9)$ & 1.81 & 1.6 \\
\hline 0.33 & 4.72 & $0.332(100.6)$ & $4.670(98.9)$ & 0.60 & -1.0 \\
\hline
\end{tabular}

* Average of four determinations.

3.4.1. Determination of Cobalt. The derivative amplitudes measured for different concentrations of $\mathrm{Co}$ (II) at appropriate wavelengths for $2 \mathrm{nd}$ and 3 rd order derivative spectra were plotted against the amount of $\mathrm{Co}$ (II) which gave linear plots in the specified concentration regions. All the parameters like detection limit, correlation coefficient, and relative standard deviation values are presented in Table 11.

3.4.2. Effect of Foreign Ions. The selectivity of the derivative methods was evaluated by studying the effect of metal ions closely associated with cobalt on its derivative amplitudes under experimental conditions. The results are presented in Table 10. The results show that the tolerance limits of Th(IV), U(VI), Mn(II), Cu(II), Ni(II), Zn(II), Sn(II), In(II), Ga(III) and $\mathrm{V}(\mathrm{V})$ which interfere seriously in zero order method were greatly enhanced in the derivative methods indicating the greater selectivity of derivative methods over the direct method.

3.4.3. Determination of Cobalt in Water and Pharmaceutical Samples by Second-Order Derivative Method. Suitable aliquots of water and pharmaceutical samples were taken and analysed for cobalt by second-order derivative method. The results obtained in the analysis of water samples by the proposed method are presented in Table 12 and the validity of the results was evaluated by adding known amounts of $\mathrm{Co}(\mathrm{II})$ and calculating their recovery percentage. The results

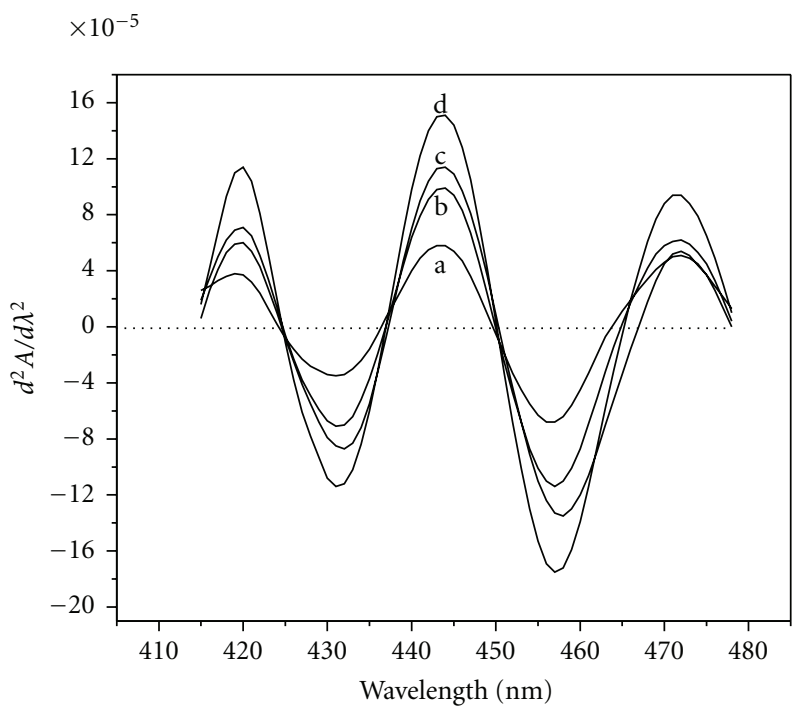

FIgure 4: Second-order derivative spectra of [Co(II)-HNAHBH]. Amount of $\mathrm{Co}(\mathrm{II}) \mu \mathrm{g} \mathrm{mL}^{-1}: \mathrm{a}=0.059, \mathrm{~b}=0.118, \mathrm{c}=0.236$, and $\mathrm{d}=$ 0.354 .

obtained with pharmaceutical samples were compared with those obtained by AAS method and presented in Table 13.

3.5. Simultaneous Second-Order Derivative Spectrophotometric Determination of Iron(II) and Cobalt(II). Iron and 
TABLE 16: Determination of iron and cobalt in alloy samples.

\begin{tabular}{|c|c|c|c|c|c|c|}
\hline \multirow{3}{*}{ Sample (composition) } & \multicolumn{4}{|c|}{ Amount (\%) } & \multicolumn{2}{|c|}{ Relative error (\%) } \\
\hline & \multicolumn{2}{|c|}{ Certified } & \multicolumn{2}{|c|}{ Found $(n=3) \pm \mathrm{SD}$} & \multirow[b]{2}{*}{$\mathrm{Fe}(\mathrm{II})$} & \multirow[b]{2}{*}{$\mathrm{Co}(\mathrm{II})$} \\
\hline & $\mathrm{Fe}(\mathrm{II})$ & $\mathrm{Co}(\mathrm{II})$ & $\mathrm{Fe}(\mathrm{II})$ & $\mathrm{Co}(\mathrm{II})$ & & \\
\hline $\begin{array}{l}\text { Elgiloy-M } \\
(20 \mathrm{Cr} ; 15 \mathrm{Ni} \text {; } 0.15 \mathrm{C} ; 2 \mathrm{Mn} ; 7 \mathrm{Mo} ; 05 \mathrm{Be})\end{array}$ & 15 & 40 & $14.82 \pm 0.15$ & $39.39 \pm 0.20$ & 1.33 & 1.52 \\
\hline $\begin{array}{l}\text { Rim alloy } \\
(17 \mathrm{Mo} ; 3 \mathrm{Mn})\end{array}$ & 68 & 12 & $69.28 \pm 0.86$ & $12.08 \pm 0.38$ & 1.88 & 0.66 \\
\hline $\begin{array}{l}\text { Sofcomag } 25 \\
\text { (Fe and Co) }\end{array}$ & 75 & 25 & $73.89 \pm 1.38$ & $25.98 \pm 0.86$ & 1.48 & 3.92 \\
\hline $\begin{array}{l}\text { Sofcomag } 49 \\
\text { (Fe and Co) }\end{array}$ & 51 & 49 & $52.12 \pm 0.35$ & $49.18 \pm 0.06$ & 2.18 & 0.36 \\
\hline
\end{tabular}

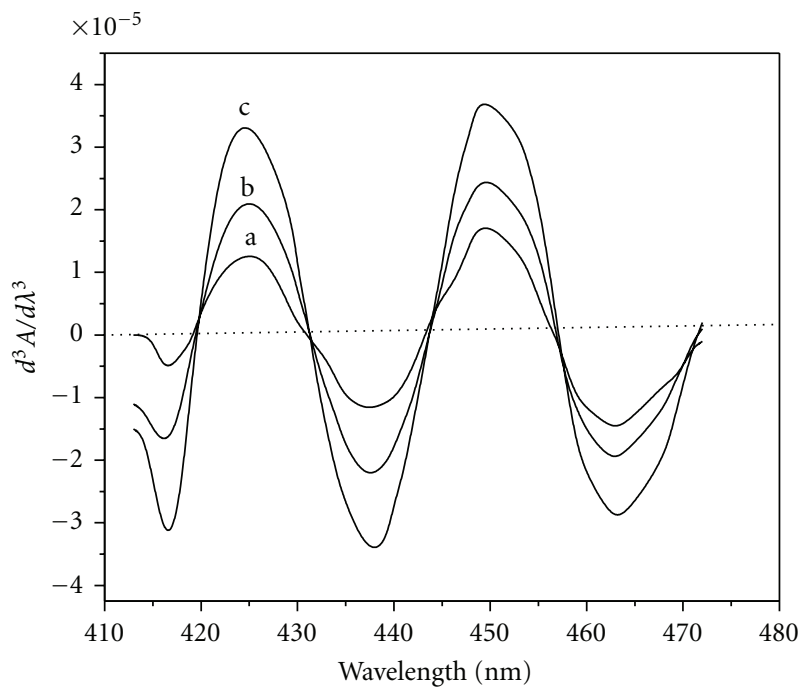

Figure 5: Third-order derivative spectra of [Co(II)-HNAHBH]. Amount of $\mathrm{Co}(\mathrm{II}) \mu \mathrm{g} \mathrm{mL}^{-1}: \mathrm{a}=0.059, \mathrm{~b}=0.118, \mathrm{c}=0.236$, and $\mathrm{d}=0.354$.

cobalt occur together in many real samples like alloy steels, biological fluids, and environmental samples. In most cases, the characterizations of these samples include the determination of their metal ion content. The need for the determination of iron and cobalt in environmental and biochemical materials has increased after reports on different roles of these metals in human health and diseases. We are now reporting a simple, sensitive, and selective second-order derivative spectrophotometric method for the simultaneous determination of $\mathrm{Fe}(\mathrm{II})$ and $\mathrm{Co}(\mathrm{II})$ using $\mathrm{HNAHBH}$ without the need to solve the simultaneous equations.

3.5.1. Derivative Spectra. The 2 nd order derivative spectra recorded for [Fe(II)-HNAHBH] and [Co(II)-HNAHBH] at $\mathrm{pH} 5.5$ showed sufficiently large derivative amplitude for cobalt at $426 \mathrm{~nm}$ while the $\mathrm{Fe}(\mathrm{II})$ species exhibit zero amplitude (Figure 6). At $436 \mathrm{~nm}$, maximum derivative amplitude was noticed for $\mathrm{Fe}(\mathrm{II})$ where there was no amplitude for $\mathrm{Co}(\mathrm{II})$. This facilitates the determination of $\mathrm{Fe}(\mathrm{II})$ and $\mathrm{Co}(\mathrm{II})$ simultaneously by measuring the second-derivative

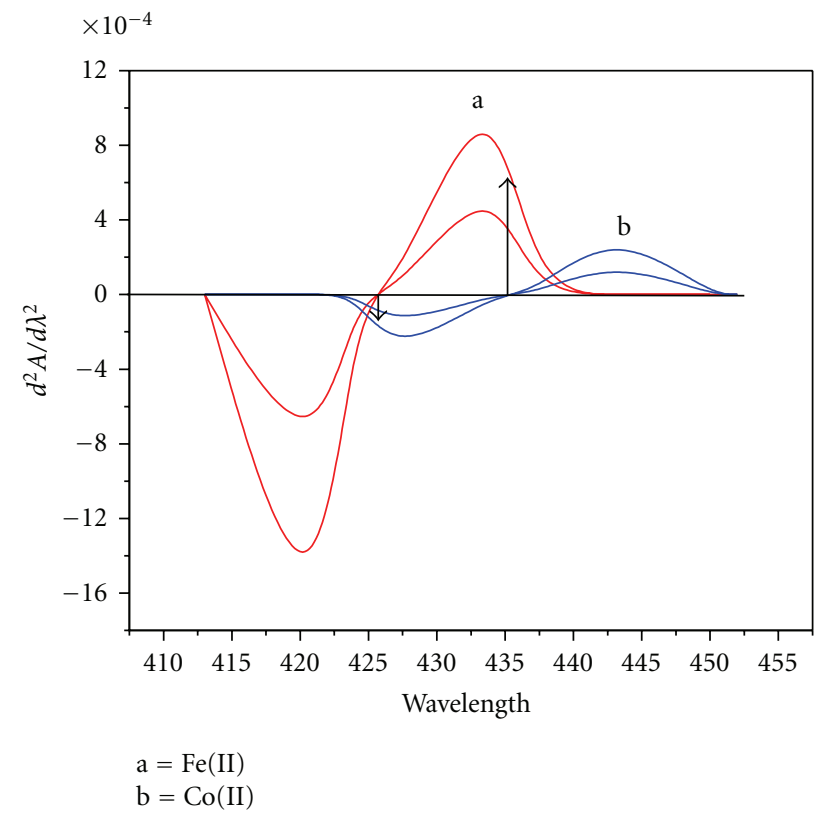

Figure 6: Second-order derivative spectra of (a) [Fe(II)-HNAHBH] and (b) $[\mathrm{Co}(\mathrm{II})-\mathrm{NAHBH}]$. Amount of Fe(II) $\left(\mu \mathrm{g} \mathrm{mL}^{-1}\right): 0.055,0.11$; Co(II) $\left(\mu \mathrm{g} \mathrm{mL}^{-1}\right): 3.53 ; 4.719$.

amplitudes of binary mixtures containing $\mathrm{Fe}(\mathrm{II})$ and $\mathrm{Co}(\mathrm{II})$ at $436 \mathrm{~nm}$ and $426 \mathrm{~nm}$, respectively.

3.5.2. Determination of $\mathrm{Fe}(\mathrm{II})$ and $\mathrm{Co}(\mathrm{II})$. Aliquots of solutions containing $0.055-1.650 \mu \mathrm{g} \mathrm{mL}^{-1}$ of $\mathrm{Fe}(\mathrm{II})$ or 0.117 $4.719 \mu \mathrm{g} \mathrm{mL}^{-1}$ of $\mathrm{Co}(\mathrm{II})$ were transferred into a series of $10 \mathrm{~mL}$ calibrated volumetric flasks. HNAHBH $\left(1 \times 10^{-2} \mathrm{M}\right.$, $0.3 \mathrm{~mL}), \mathrm{CTAB}(1 \%, 1.5 \mathrm{~mL})$, and buffer solution ( $\mathrm{pH} 5.5$, $4 \mathrm{~mL}$ ) were added to each of these flasks and diluted to the mark with distilled water. The zero-crossing points of $[\mathrm{Fe}(\mathrm{II})-\mathrm{HNAHBH}]$ and $[\mathrm{Co}(\mathrm{II})-\mathrm{HNAHBH}]$ species were determined by recording the second-order derivative spectra of both the systems with reference to the reagent blank. Calibration plots for the determination of $\mathrm{Fe}(\mathrm{II})$ and $\mathrm{Co}(\mathrm{II})$ were constructed by measuring the second-derivative amplitudes at zero crossing points of [Co(II)-HNAHBH] $(436 \mathrm{~nm})$ and $[\mathrm{Fe}(\mathrm{II})-\mathrm{HNAHBH}](426 \mathrm{~nm})$, respectively, and plotting 


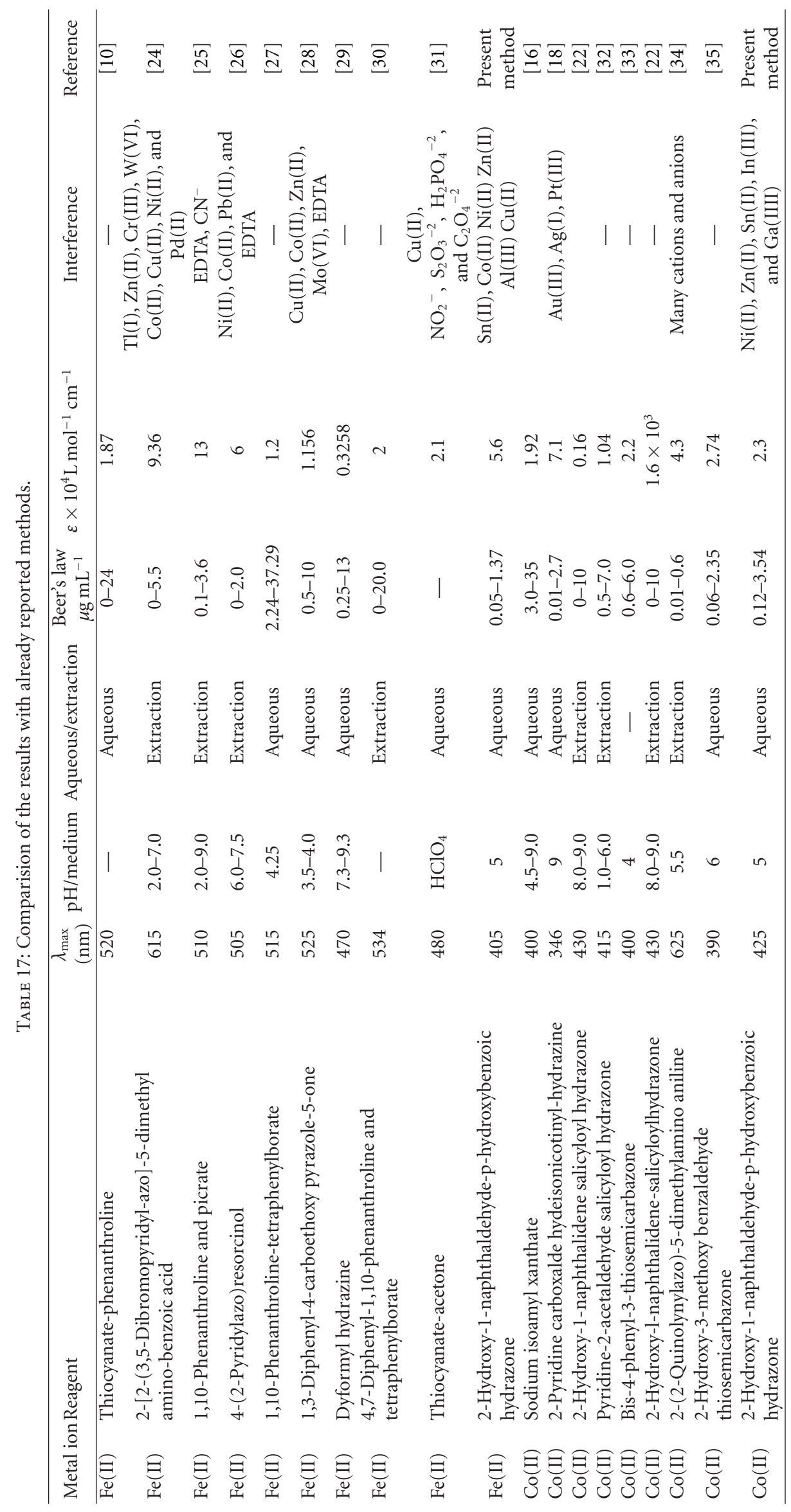


against the respective analyte concentrations. $\mathrm{Fe}(\mathrm{II})$ and $\mathrm{Co}(\mathrm{II})$ obeyed Beer's law in the range $0.055-1.650 \mu \mathrm{g} \mathrm{mL}^{-1}$ and $0.117-4.719 \mu \mathrm{g} \mathrm{mL}^{-1}$ at $436 \mathrm{~nm}$ and $426 \mathrm{~nm}$, respectively. Calibration plots were constructed for the standard solutions containing $\mathrm{Fe}(\mathrm{II})$ alone and in the presence of $0.589 \mu \mathrm{g} \mathrm{mL}-1$ of $\mathrm{Co}(\mathrm{II})$. Similarly, the calibration graphs were constructed for standards containing $\mathrm{Co}(\mathrm{II})$ alone and in the presence of $0.330 \mu \mathrm{g} \mathrm{mL} L^{-1}$ of $\mathrm{Fe}(\mathrm{II})$. The slopes, intercepts, and correlation coefficients of the prepared calibration plots were calculated and given in Table 14. The derivative amplitudes measured at $436 \mathrm{~nm}$ and $426 \mathrm{~nm}$ were found to be independent of the concentration of $\mathrm{Co}$ (II) and $\mathrm{Fe}(\mathrm{II})$, respectively. This allows the determination of $\mathrm{Fe}(\mathrm{II})$ and $\mathrm{Co}(\mathrm{II})$ in their mixtures without any significant error and without the need for their prior separation.

3.5.3. Simultaneous Determination of $\mathrm{Co}(\mathrm{II})$ and $\mathrm{Fe}(\mathrm{II})$ in Binary Mixtures. $\mathrm{Fe}(\mathrm{II})$ and $\mathrm{Co}(\mathrm{II})$ were mixed in different proportions and then treated with required amount of HNAHBH in the presence of buffer solution $(\mathrm{pH}$ 5.5) and $0.15 \%$ of $\mathrm{CTAB}$ and diluted to the volume in $10 \mathrm{~mL}$ volumetric flasks. The second-order derivative spectra for these solutions were recorded $(350-600 \mathrm{~nm})$ and the derivative amplitudes were measured at $436 \mathrm{~nm}$ and $426 \mathrm{~nm}$. The amounts of $\mathrm{Fe}$ (II) and $\mathrm{Co}$ (II) in the mixtures taken were calculated from the measured derivative amplitudes using the respective predetermined calibration plots. The results obtained along with the recovery percentage and relative errors are presented in Table 15, which indicate the usefulness of the proposed method for the simultaneous determination of $\mathrm{Fe}(\mathrm{II})$ and $\mathrm{Co}(\mathrm{II})$ in admixtures.

3.5.4. Simultaneous Determination of Iron and Cobalt in Alloy Samples. The developed second-order derivative spectrophotometric method was employed for the simultaneous determination of iron and cobalt in some alloy samples. Appropriate volumes of the alloy samples were treated with required amount of $\mathrm{HNAHBH}$ at $\mathrm{pH} 5.5$ in the presence of $0.15 \% \mathrm{CTAB}$ and diluted to $10 \mathrm{~mL}$ in standard flasks. The second-derivative curves for the resultant solutions were recorded, and the derivative amplitudes were measured at $426 \mathrm{~nm}$ and $436 \mathrm{~nm}$. The amounts of iron and cobalt in the samples were evaluated with the help of predetermined calibration plots and presented in Table 16.

\section{Conclusions}

A comparison of the analytical results of the proposed methods was made with those of some of the recently reported spectrophotometric methods and presented in Table 17. The data in the above table reveals that the proposed method of determination of iron is more sensitive than those reported by Malik and Rao [27], Patil and Dhuley [28], Nagabhushana et al. [29], Wang et al. [30], Zhang et al. [31], and Martins et al. [36]. The methods proposed by Katmal and Hoyakava [24], Morales and Toral [25], and Reddy et al. [26] are more sensitive than the present method. However they are less selective than the proposed method as they suffer interference from $\mathrm{W}(\mathrm{VI}), \mathrm{Pd}(\mathrm{II}), \mathrm{Cr}(\mathrm{III}), \mathrm{Tl}(\mathrm{I})$, $\mathrm{Pb}(\mathrm{II}), \mathrm{Bi}(\mathrm{III}), \mathrm{Hg}(\mathrm{II}), \mathrm{Mo}(\mathrm{VI}), \mathrm{EDTA}, \mathrm{CN}^{-}$. Regarding the determination of cobalt, the present method is more sensitive than those reported by Malik et al [16], Patil and Sawant [32], Adinarayana Reddy et al. [33], and Prabhulkar et al. [22]. However, the preset method is less sensitive than the methods reported by Guzor and Jin [21] and Qiufen et al. [34], but these methods are less selective due to the interference of many cations and anions. The results obtained in the simultaneous determination of $\mathrm{Fe}(\mathrm{II})$ and $\mathrm{Co}(\mathrm{II})$ are well comparable with the reported methods. Above all most of the reported methods involve extraction into spurious organic solvents where as the present methods are simple, nonextractive, and reasonably accurate.

\section{References}

[1] E. Wildermuth, H. Stark, G. Friedrich et al., "Iron compounds," in Ullmann's Encyclopedia of Industrial Chemistry, Wiley-VCH, 2000.

[2] F. C. Campbell, "Cobalt and cobalt alloys," in Elements of Metallurgy and Engineering Alloys, pp. 557-558, ASM International, 2008.

[3] M. L. C. Adolfsson, A. K. Saloranta, and M. K. Silander, "Colourant composition for paint products," US Patent, Patent number: 5985987, 1999.

[4] M. W. Hentze and L. C. Kühn, "Molecular control of vertebrate iron metabolism: mRNA-based regulatory circuits operated by iron, nitric oxide, and oxidative stress," Proceedings of the National Academy of Sciences of the United States of America, vol. 93, no. 16, pp. 8175-8182, 1996.

[5] R. Michel, M. Nolte, M. Reich, and F. Loer, "Systemic effects of implanted prostheses made of cobalt-chromium alloys," Archives of Orthopaedic and Trauma Surgery, vol. 110, no. 2, pp. 61-74, 1991.

[6] J. A. Disegi, R. L. Kennedy, and R. Pillia, Cobalt-Base Alloys for Biomedical Applications, ASTM International Standards, 1999.

[7] J. T. Ellis, I. Schulman, and C. H. Smith, "Generalized siderosis with fibrosis of liver AND pancreas in cooley's (Mediterranean) anemia with observations on the pathogenesis of the siderosis AND fibrosis," American Journal of Pathology, vol. 30, no. 2, pp. 287-309, 1954.

[8] Wu, Li-Xiang, Guo, and J. Cun, Metallurgical Analysis, vol. 24, no. 3, pp. 66-68, 2004.

[9] L. Zaijun, F. You, L. Zhongyun, and T. Jian, "Spectrophotometric determination of iron(III)-dimethyldithiocarbamate (ferbam) using 9-(4-carboxyphenyl)-2,3,7-trihydroxyl-6fluorone," Talanta, vol. 63, no. 3, pp. 647-651, 2004.

[10] Qi-Kai Zhang, Ling-Zhao Kong, and Li Wang, "Spectrophotometric determination of micro amount of iron in oils with thiocyanate-phenanthroline-OP," Fenxi Shiyanshi (Analytical Laboratory), vol. 24, no. 1, pp. 77-79, 2005.

[11] P. K. Tarafder and R. Thakur, "Surfactant-mediated extraction of iron and its spectrophotometric determination in rocks, minerals, soils, stream sediments and water samples," Microchemical Journal, vol. 80, no. 1, pp. 39-43, 2005.

[12] F. G. Martins, J. F. Andrade, A. C. Pimenta, L. M. Lourenco, J. R. M. Casto, and V. R. Balbo, "Spectrophotometric study of iron oxidation in the iron(II)/thiocyanate/acetone system and some analytical applications," Eclética Química, vol. 30, no. 3, pp. 63-71, 2005. 
[13] A. K. Sharma and I. Singh, "Spectrophotometric trace determination of iron in food, milk, and tea samples using a new bis-azo dye as analytical reagent," Food Analytical Methods, vol. 2, no. 3, pp. 221-225, 2009.

[14] L. I. Cheng-hong, G. E. Chang-hua, L. Hua-ding, and P. Fuyou, "Spectrophotometric determination of iron with 2-(5carboxy-1,3,4-triazolylazo)-5-diethylamino aniline ," Science Technology and Engineering, vol. 21, pp. 5780-5782, 2008.

[15] Q. Z. Zhai, "Catalytic kinetic spectrophotometric determination of trace copper with copper(II)-p-acetylchlorophosphonazo-hydrogen peroxide system," Bulletin of the Chemical Society of Ethiopia, vol. 23, no. 3, pp. 327-335, 2009.

[16] A. K. Malik, K. N. Kaul, B. S. Lark, W. Faubel, and A. L. J. Rao, "Spectrophotometric determination of cobalt, nickel palladium, copper, ruthenium and molybdenum using sodium isoamylxanthate in presence of surfactants," Turkish Journal of Chemistry, vol. 25, no. 1, pp. 99-105, 2001.

[17] B. R. Reddy, P. Radhika, J. R. Kumar, D. N. Priya, and K. Rajgopal, "Extractive spectrophotometric determination of cobalt(II) in synthetic and pharmaceutical samples using cyanex 923," Analytical Sciences, vol. 20, no. 2, pp. 345-349, 2004.

[18] G. A. Shar and G. A. Soomro, "Spectrophotometric determination of cobalt(II), nickel(II) and copper (II) with 1-(2 pyridylazo)-2-naphthol in micellar medium," The Nucleus, vol. 41, pp. 77-82, 2004.

[19] N. Veerachalee, P. Taweema, and A. Songsasen, "Complexation and spectrophotometric determination of cobalt(II) ion with 3-(2'-thiazolylazo)-2,6-diaminopyridine," Kasetsart JournalNatural Science, vol. 41, no. 4, pp. 675-680, 2007.

[20] Y. Haoyi, Z. Guoxiu, and Y. Gaohua, "Determination of cobalt in terephthalic acid by picramazochrom spectrophotometry," Chemical Analysis and Meterage, vol. 1, 2009.

[21] S. H. Guzar and Q. H. Jin, "Simple, selective, and sensitive spectrophotometric method for determination of trace amounts of nickel(II), copper (II), cobalt (II), and iron (III) with a novel reagent 2-pyridine carboxaldehyde isonicotinyl hydrazone," Chemical Research in Chinese Universities, vol. 24, no. 2, pp. 143-147, 2008.

[22] S. G. Prabhulkar and R. M. Patil, "2-Hydroxy-1-naphthalidine salicylohydrazone as an analytical reagent for extractive spectrophotometric determination of a biologically and industrially important metal Cobalt(II)," International Journal of Chemical Sciences, vol. 6, no. 3, pp. 1480-1485, 2008.

[23] J. E. Huheey, E. A. Keiter, and R. L. Keiter, Inorganic Chemistry, Harper Collins, New York, NY, USA, 4th edition, 1993.

[24] T. Katami, T. Hayakawa, M. Furukawa, and S. Shibata, "Extraction-spectrophotometric determination of iron with 2-[2-(3,5-Dibromopyridyl)azo]-5-dimethylaminobenzoic acid," The Analyst, vol. 109, no. 2, pp. 159-162, 1984.

[25] A. Morales and M. I. Toral, "Extraction-spectrophotometric determination of iron as the ternary tris(1,10-phenanthroline)-iron(II)-picrate complex," The Analyst, vol. 110, no. 12, pp. 1445-1449, 1985.

[26] M. R. P. Reddy, P. V. S. Kumar, J. P. Shyamsundar, and J. S. Anjaneyulu, "Extractive spectrophotometric method for the determination of iron in titanium base alloys using 4-(2-Pyridylazo) resorcinol and a long chain quaternary ammonium salt," Journal of the Indian Chemical Society, vol. 66, pp. 437-439, 1989.

[27] A. K. Malik and A. L. J. Rao, "Spectrophotometric determination of iron(III) dimethyldithiocarbamate (ferbam)," Talanta, vol. 44, no. 2, pp. 177-183, 1997.
[28] R. K. Patil and D. G. Dhuley, "Solvent extraction and spectrophotometric determination of Fe(II) with 1,3-diphenyl-4carboethoxy pyrazole-5-one," Indian Journal of Chemistry, vol. 39, no. 10, pp. 1105-1106, 2000.

[29] B. M. Nagabhushana, G. T. Chandrappa, B. Nagappa, and N. H. Nagaraj, "Diformylhydrazine as analytical reagent for spectrophotometric determination of iron(II) and iron(III)," Analytical and Bioanalytical Chemistry, vol. 373, no. 4-5, pp. 299-303, 2002.

[30] L. M. Wang, C. Song, and J. Jin, "Spectrophotometric determination of iron by extraction of its ternary complex with 4,7-diphenyl-1,10-phenanthroline and tetraphenylborate into molten naphthalene," Fenxi Shiyanshi (Analytical Laboratory), vol. 23, no. 9, pp. 48-50, 2004.

[31] F. G. Martins, J. F. Andrade, A. C. Pimenta, L. M. Lourenco, J. R. M. Casto, and V. R. Balbo, "Spectrophotometric study of iron oxidation in the iron(II) thiocyanateacetone system and some analytical application," Electica Quimica, vol. 30, no. 3, pp. 63-71, 2005.

[32] S. S. Patil and A. D. Sawant, "Pyridine-2-acetaldehyde salicyloylhydrazone as reagent for extractive and spectrophotometric determination of cobalt(II) at trace level," Indian Journal of Chemical Technology, vol. 8, no. 2, pp. 88-91, 2001.

[33] S. Adinarayana Reddy, K. Janardhan Reddy, S. Lakshmi Narayana, Y. Sarala, and A. Varada Reddy, "Synthesis of new reagent 2,6-diacetylpyridine bis-4-phenyl-3- thiosemicarbazone (2,6-DAPBPTSC): Selective, sensitive and extractive spectrophotometric determination of $\mathrm{Co}$ (II) in vegetable, soil, pharmaceutical and alloy samples," Journal of the Chinese Chemical Society, vol. 55, no. 2, pp. 326-334, 2008.

[34] Q. Qiufen, G. Yang, X. Dong, and J. Yin, "Study on the solid phase extraction and spectrophotometric determination of cobalt with 2-(2-quinolylazo)-5-diethylaminoaniline," Turkish Journal of Chemistry, vol. 28, no. 5, pp. 611-619, 2004.

[35] A. P. Kumar, P. R. Reddy, and V. K. Reddy, "Direct and derivative spectrophotometric determination of cobalt (II) in microgram quantities with 2-hydroxy-3-methoxy benzaldehyde thiosemicarbazone," Journal of the Korean Chemical Society, vol. 51, no. 4, pp. 331-338, 2007.

[36] F. G. Martins, J. F. Andrade, A. C. Pimenta, L. M. Lourenço, J. R. M. Castro, and V. R. Balbo, "Spectrophotometric study of iron oxidation in the iron(II)/thiocyanate/ acetone system and some analytical applications," Ecletica Quimica, vol. 30, no. 3, pp. 63-71, 2005. 


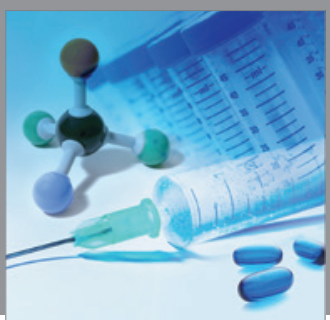

International Journal of

Medicinal Chemistry

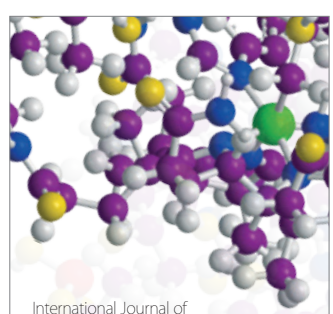

Carbohydrate Chemistry

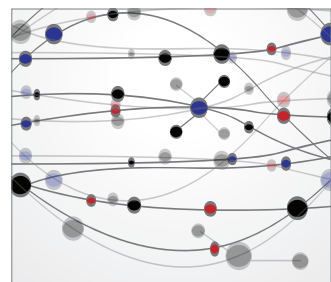

The Scientific World Journal
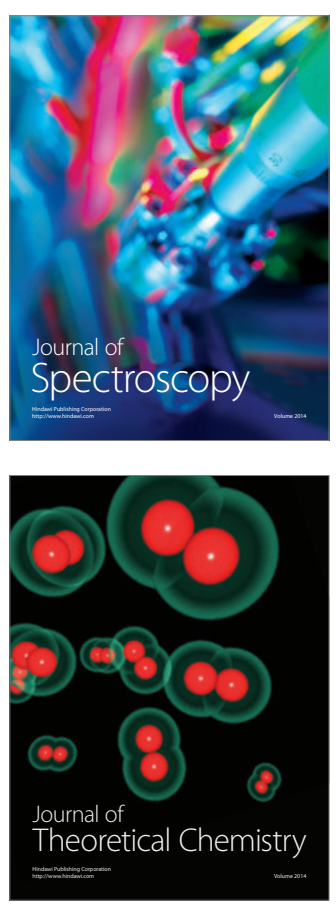
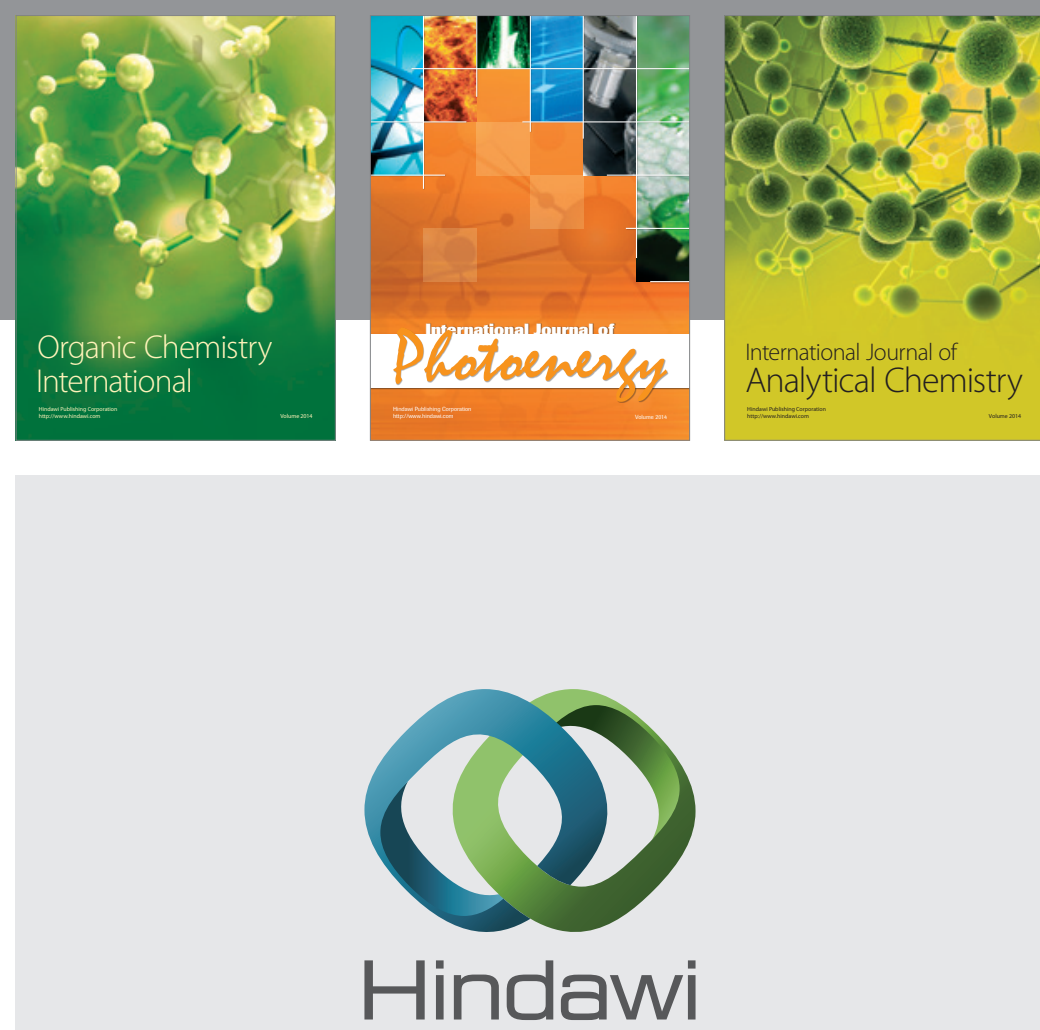

Submit your manuscripts at

http://www.hindawi.com
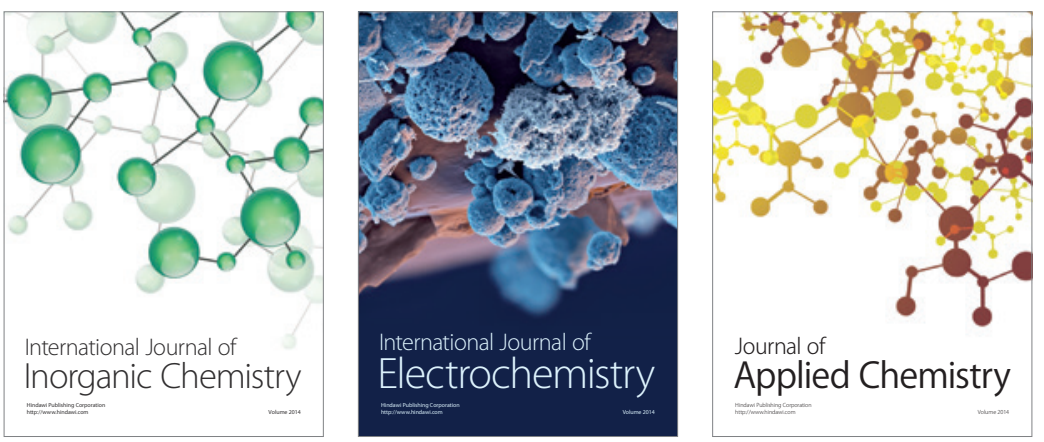

Journal of

Applied Chemistry
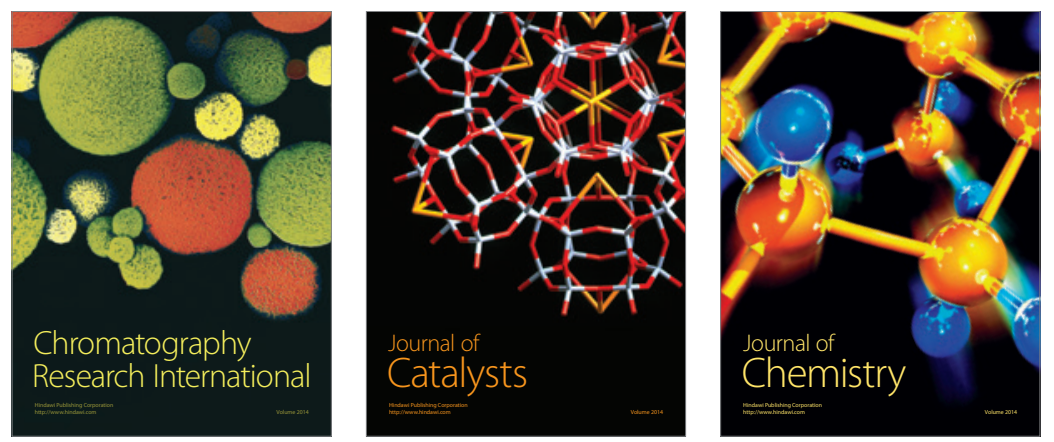
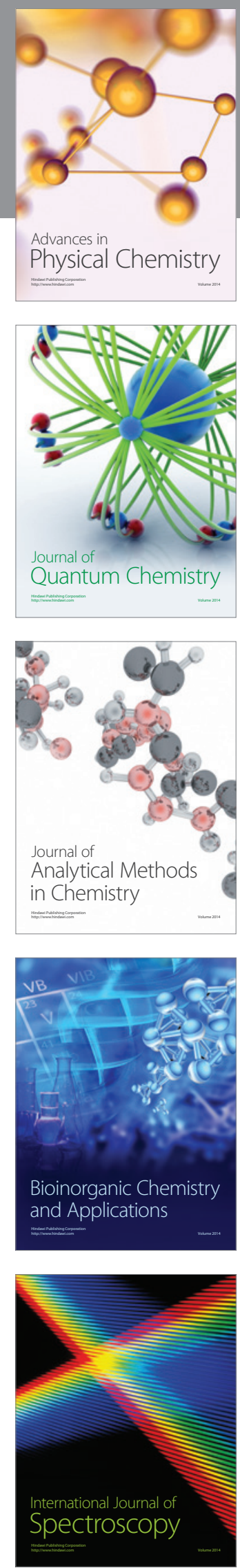